\title{
DISTRIBUTION PATTERN AND HABITAT PREFERENCE OF THE BLACK FRANCOLIN (FRANCOLINUS FRANCOLINUS ASIAE) IN UTTARAKHAND, INDIA
}

\author{
${\text { Priyanka Negi }{ }^{*} \text { and Pramesh Lakhera }}^{\mathrm{b}}$
}

H. N. B. Garhwal University, Srinagar Garhwal, India

*Corresponding author. Email: pn.zoology@gmail.com

\author{
Article history \\ Received: 29 March 2017; \\ accepted 2 January 2019

\section{Keywords:} \\ Altitude; Black Franco- \\ lin; conservation; habitat \\ preference; Uttarakhand
}

\begin{abstract}
Research activities on the Black Francolin in the Himalayan region are very limited, and its status in this region is rather unknown. So, the main focus of our study was on the assessment of its distribution, habitat preference and abundance at different altitudes. The current study was conducted at an altitude of 100-2000 $\mathrm{m}$ in Uttarakhand State, India. The bird survey was carried out employing the trail walk method. Bird abundance, habitat preference and vegetation characterization were estimated by encounter rate, using correlative approach and quadrate methods, respectively. This study shows that the abundance of this bird species is increasing along an altitudinal gradient, while below the $500 \mathrm{~m}$ altitude it is lower. The obtained data on habitat preference show that an altitude above $500 \mathrm{~m}$, this bird prefers cultivated fields with abandoned land (CL + AL) > cultivated land with forest edges $(\mathrm{CL}+\mathrm{FE})>$ crop land $(\mathrm{CL})$ and at an altitude below $500 \mathrm{~m}$, it shows preference for crop land $(\mathrm{CL})>$ cultivated fields with abandoned land $(\mathrm{CL}+\mathrm{AL})>$ cultivated land with forest edges $(\mathrm{CL}+\mathrm{FE})$. In the pure forest type, the Black Francolin was not encountered (no encounter rate). The roosting and nesting patterns of the Black Francolin also indicate its preference for an agro- ecosystem.
\end{abstract}

\section{INTRODUCTION}

Species survival highly depends on the surroundings where it lives, i.e. habitat. A habitat provides an organism not only with food but also with shelter, protection and space to live and to breed. In the case of species evolution, habitat preference also acts as evolutionary pressure (Cody 1985). Studies on birds with habitat preference describe their factual role in species distribution and subspecies evolution. The Himalaya is known for its rich biodiversity. The altitude of the Himalayan mountains considerably varies within small geographical areas causing great changes in the habitat therein. This provides us with a great opportunity for studying the role of habitat in subspecies formation. Several species of Galliformes are widely distributed across the Himalayan ranges from far north to east. However, their distribution is not uniform. They are distributed in similar types of habitat in a patchy manner. This may be due to the recent changes in the pattern of land use across the Himalayan ranges and habitat destruction, which is often accompanied by habitat fragmentation. Thus, studies on Galliformes habitats are of the utmost importance in assessing the impact of habitat destruction and speciation in the Himalaya.

Being a ground dwelling game bird, the Black Francolin is an ideal choice for studying habitat preference in birds in the Himalayan ecosystem. The Black Francolin has six morphological subspecies, which are distributed from West to East across the Indian subcontinent (Forcina et al. 2012; McGowan and Kirwan 2015). In comparison with other Galliformes species, the population of the Black Francolin is stable, which is due to its wide range of distribution (Birdlife International 2015). However, a few studies conducted in European countries have reported that in some areas this species is on decline as a result of overhunting (Johnsgard 1988; Tucker and Heath 1994). The IUCN red list 2016 for Bangladesh shows that this species has come into the category of endangered species. In India, this bird is still considered a common bird and very few scientific studies have been carried out yet. The habitat preference, reproduction and behavioral biology of such species of Galliformes as Kalij pheasant (Lophura leucomelanos), Cheer pheasant (Catreus wallichii), Red jungle fowl (Gallus gallus), Chukar (Alectoris chukar) etc. have been studied extensively (Bisht, Lakhera, and ChandolaSaklani 1990; Chandola-Saklani, Lakhera, and Sharma 1988; Chandola-Saklani et al. 1994; Ramesh, Sathyakumar, and Rawat 1994; Kukreti, Phurailatpam, and Bisht 2005; Kumar and Bisht 2011), but there are still no significant studies on the Black Francolin.

Reliable and sufficient information regarding the Black Francolin at higher altitudes of India is lacking. So, the present study aimed to investigate the habitat preference, distribution and abundance of Francolinus asiae in the 
Himalayan State Uttarakhand. Findings of this study are expected improve the management of this bird, which is greatly dependent on the understanding of the relationship between species and their specific habitats. This study is also expected to provide the baseline data for further investigation of this species abundance in the Himalayan Ecosystem.

\section{MATERIALS AND METHODS}

\section{Study Area}

The study was carried out in Uttarakhand, which is located in the Indian Himalayan Region between $28^{\circ} 44^{\prime} \mathrm{N}$ and $31^{\circ} 28^{\prime} \mathrm{N}$ latitudes and $77^{\circ} 35^{\prime} \mathrm{E}$ and $81^{\circ} 01^{\prime} \mathrm{E}$ longitudes and covers a geographical area of $53,483 \mathrm{~km}^{2}$. The study sites are characterized by a wide range of altitudinal and climatic variation offering varied vegetation and habitat for wildlife. The study area was stratified into four strata according to altitudinal zones: 1) $<500 \mathrm{~m}$, 2) $500-1000$ m, 3) 1000-1500 m, 4) 1500-2000 m. In each altitudinal zone, the study sites were selected on the basis of pilot surveys and the information provided by local people, bird watchers and field biologists. Having obtained the information on the distribution of the Black Francolin, we selected 3-4 sites for its extensive studies.

\section{Data collection}

The study was carried during the 2012-2013 breeding season (from March to September) because during this period bird activity could be observed more easily (Ali 2002). At every site, two $2 \mathrm{~km}$-long trail walks were laid down. Data were collected at every site in the morning (6:00-9:00 am) for three consecutive days at three-month intervals. For characterization of study sites, vegetation sampling was carried employing the quadrate method (Schemnitz 1980). The altitude and the GPS position of each bird sighting were recorded. Based on the sighting in every altitudinal range, the habitats were divided into four groups: Cultivated land (CL), Cultivated land with abandoned fields $(\mathrm{CL}+$ $\mathrm{AL})$, Forest edge with cultivated land (CL $+\mathrm{FA})$ and Forest types (F).

\section{Data Analysis}

The encounter rate method was used to estimate the Black Francolin's abundance, which was measured by the number of bird sightings per unit effort (Caughley 1975; Rodgers 1991). Habitat preference was estimated using the correlative approach (Kidwai et al. 2011; Soldatini, Albores-Barajas, and Pellizzi 2010), i.e. by calculating the ratio of the number of bird sightings in each habitat type to the total number of sightings. In this method, the species abundance was related to its major habitat types that had been identified during trail walking. Kruskal-Wallis test (one-way ANOVA) was performed to test the null hypothesis that across habitat and altitude the bird is found identically.

\section{RESULTS}

\section{Population abundance}

Along an altitudinal gradient, the maximum encounter rate (ER) was observed at 1500-2000 m a.s.1 (4.25 \pm $0.53 \mathrm{birds} / \mathrm{km}$ ) followed by that at $1000-1500 \mathrm{~m}$ a.s.l. $(3.60 \pm 0.70 \mathrm{birds} / \mathrm{km})$. The lower ER $(2.20 \pm 0.2)$ was observed in habitats at an altitude lower than $500 \mathrm{~m}$ a.s.1 (Table 1 and Figure 1). The Kruskal-Wallis statistical test showed a significant difference in the abundance of the Black Francolin with altitude $\left(\mathrm{HChi}^{2}\right.$ test $=18.78$, $p<0.001)$.

\section{Habitat Preference}

The habitat type preferred by the Black Francolin most was CL + AL (50.67\%) followed by CL (28.30\%). CL + FE $(21.44 \%)$ was another type of habitat preferred

Table 1. Encounter rate (ER) of the Black Francolin at different study sites and in different altitudinal ranges.

\begin{tabular}{|c|c|c|c|c|c|}
\hline S. No. & Altitudinal class (m) & Site name & Altitude (m) & ER & Overall ER \\
\hline 1 & & Haridwar & 288 & $2.6 \pm 0.10$ & \\
\hline 2 & $<500$ & Sitarganj & 300 & $2.0 \pm 0.20$ & $2.20 \pm 0.20$ \\
\hline 3 & & Dehradun & 448 & $2.0 \pm 0.20$ & \\
\hline 4 & & Srinagar & 700 & $5.0 \pm 0.65$ & \\
\hline 5 & $500-1000$ & Augstyamuni & 820 & $0.8 \pm 0.10$ & $3.02 \pm 1.22$ \\
\hline 6 & & Jalai & 1095 & $3.25 \pm 0.37$ & \\
\hline 7 & & Bhutoli & 1390 & $5.0 \pm 0.62$ & \\
\hline 8 & $1000-1500$ & Mayali & 1480 & $2.8 \pm 0.2$ & $3.60 \pm 0.70$ \\
\hline 9 & & Jakholi & 1500 & $3.0 \pm 0.2$ & \\
\hline 10 & & Nanital & 1530 & $3.0 \pm 0.4$ & \\
\hline 11 & $1500-2000$ & Gopeshwer & 1630 & $5.0 \pm 0.37$ & $4.25 \pm 0.53$ \\
\hline 12 & & Mandal & 1730 & $3.75 \pm 0.25$ & \\
\hline 13 & & Nagthath & 1846 & $5.25 \pm 0.25$ & \\
\hline
\end{tabular}


by this bird across all the altitudinal region. In the pure forest type, the abundance of the Black Francolin was negligible (Figure 2). At a lower altitude, i.e. lower than $500 \mathrm{~m}$, the Black Francolin showed preference for CL (57.17\%) over CL + AL (36.15\%) and CL + FE (6.66\%) (Figure 2). The Kruskal-Wallis statistical test showed that habitat preference of the Black Francolin significantly varied with different habitat types $\left(\mathrm{HChi}^{2}\right.$ test $\left.=26.08, p<0.05\right)$.

\section{Vegetation Characteristics}

In the habitats preferred by the Black Francolin, we recorded a total of 83 preferred plant species (trees $=13$, shrubs $=20$, herbs $=28$, grasses $=22$ ). During the study, four tree species (Grewia optiva, Ficus roxburghii, Ficus palmata, Pyrus pashia), three shrub species (Carissa opaca, Ageratina adenophora, Boehmeria platyphylla), seven herb species (Artemisia japonica, Ageratum cynozoides, Aechmanthera gossypina, Bidens pilosa, Oxalis latifolia, Reinwardtia indica, Eupatorium sp.) and three grass species (Imperata cylindrical, Heteropogon contortus, Poa sp.) were found in all habitat types. The remaining plant species observed were site-specific

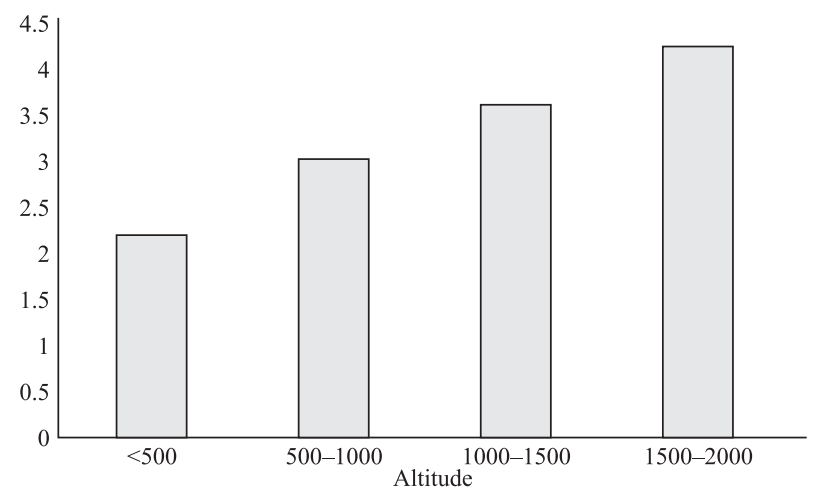

Figure 1. Encounter rate of the Black Francolin at different altitudes: $\mathrm{X}$-axis indicates different altitudinal ranges of Uttarakhand, Y-axis indicates encounter rate of the Black Francolin.

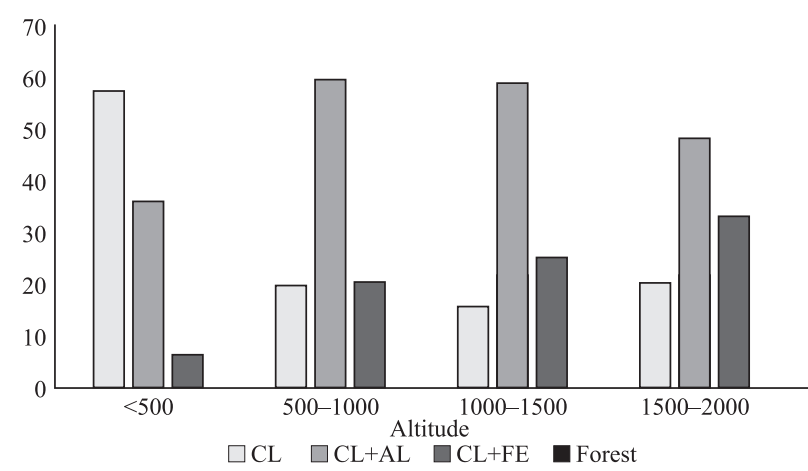

Figure 2. Different habitat preference of the Black Francolin: $\mathrm{X}$-axis indicates different altitudinal range of Uttarakhand, Y-axis indicates percentage of different types of habitat preferred by the Black Francolin. Green arrow shows the absence of the Black Francolin in forest.
Table 2. Plants preferred by the Black Francolin for roosting.

\begin{tabular}{|l|c|}
\hline \multicolumn{1}{|c|}{ Plant species } & Percent Frequency \\
\hline Rubus ellipticus & 16.59 \\
\hline Rosa brunonii & 14.89 \\
\hline Artemisia japonica & 13.43 \\
\hline Rubus niveus & 12.27 \\
\hline Artemisia nilagirica & 10.84 \\
\hline Ziziphus sp. & 8.25 \\
\hline Lantana camara & 7.89 \\
\hline Eupatorium sp. & 7.50 \\
\hline Acasia sp. & 2.95 \\
\hline Carissa opaca & 2.84 \\
\hline Ficus palmata & 1.45 \\
\hline Ficus roxburghii & 1.10 \\
\hline Total & 100 \\
\hline
\end{tabular}

(Appendix 1).

\section{Roosting}

At all study sites, for roosting, the Black Francolin preferred 12 plant species ( 6 shrubs, 3 herbs and 3 medium sized trees). The most preferred plant species included Rubus ellipticus (16.59\%), Rosa brunonii (14.89\%), Artemisia japonica (13.43\%) and Rubus niveus (12.27\%), while Ficus roxburghii (1.10\%) and Ficus palmata $(1.45 \%)$ were less preferred (Table 2$)$.

\section{Nesting}

During the survey, 10 nests of the Black Francolin were located. Out of these, $80 \%$ were found on the ground associated with sloppy crop field edges under permanent grass cover and the remaining $20 \%$ in wheat fields. The size of the observed clutches, $60.0 \pm 0.13 \%$ of which survived (Fledgling Success), was $6.3 \pm 0.26$ eggs. The hatching success of the Black Francolin in the nests located along crop field edges reached $87.5 \%$. However, all eggs from crop fields were reported destroyed. The $100 \%$ hatching success was recorded in $40 \%$ of clutches, while in $30 \%$ of clutches it was estimated at $66 \%$, and the remaining $30 \%$ of nests were found to have been destroyed. The most common nest building materials used by this bird were such grass species as Imperata cylindrica, Saccharum filifolium, Cynodon dactylon, dry wheat leaves and debris. The nests were found in shallow depressions surrounded by grass tuft and dry grasses (Table 3 ).

\section{DISCUSSION}

This is the very first in-depth study on the Black Francolin's habitat preference in the western Himalaya. Our results indicate high abundance of this bird at higher altitudes. However, this species has a wide distribu- 
Table 3. Nesting patterns of the Black Francolin in different areas of Uttarakhand.

\begin{tabular}{|c|c|c|c|c|}
\hline Nest & Material used for nest building & Location & Clutch Size $(\mathrm{N})$ & \%Survival \\
\hline $\mathrm{a}$ & On the ground in soil, Imperata sp. leaves and stems & Field Edge & 7 & $100 \%$ \\
\hline $\mathrm{b}$ & $\begin{array}{l}\text { On the ground in soil, leaves and twigs of wheat and } \\
\text { leaves of wild peas }\end{array}$ & $\begin{array}{l}\text { Middle of the crop } \\
\text { field }\end{array}$ & 8 & 0 \\
\hline $\mathrm{c}$ & $\begin{array}{l}\text { On the ground in soil, leaves of Saccharum filifolium } \\
\text { and Imperata lindrica }\end{array}$ & Field Edge & 6 & $66 \%$ \\
\hline $\mathrm{d}$ & $\begin{array}{l}\text { On the ground in soil, leaves of Cynodon dactylon and } \\
\text { leaves of Pinus sp. }\end{array}$ & Field Edge & 6 & $100 \%$ \\
\hline $\mathrm{e}$ & $\begin{array}{l}\text { On the ground in soil, leaves of Saccharum filifolium } \\
\text { and Imperata cylindrical }\end{array}$ & Field Edge & 5 & $100 \%$ \\
\hline f & $\begin{array}{l}\text { On the ground in soil, leaves and twigs of wheat and } \\
\text { Imperata leaves }\end{array}$ & Field Edge & 6 & $66 \%$ \\
\hline $\mathrm{g}$ & On the ground in soil, Imperata sp. leaves and debris & Field Edge & 6 & $100 \%$ \\
\hline $\mathrm{h}$ & On the ground in soil, ferns, debris, dry leaves & Field Edge & 7 & $66 \%$ \\
\hline $\mathrm{i}$ & $\begin{array}{l}\text { Leaves and stems of Imperata sp. and leaves of Pinus } \\
\text { sp. }\end{array}$ & Field Edge & 6 & 0 \\
\hline $\mathrm{j}$ & $\begin{array}{l}\text { On the ground in soil, leaves and twigs of wheat and } \\
\text { leaves of wild peas }\end{array}$ & Middle of the Field & 6 & 0 \\
\hline \multicolumn{3}{|r|}{ Mean \pm S. E. } & $6.30 \pm 0.26$ & $60.0 \pm 0.13$ \\
\hline
\end{tabular}

tion across altitudinal ranges. The high encounter rate of this bird at different altitudes may be explained by destruction and fragmentation of the habitat in the below $500 \mathrm{~m}$ altitudinal zone as a result of urbanization and industrialization. The higher-elevation areas in the Himalayan ecosystem are still somehow less disturbed, so populations of this bird species are found at higher elevation in the 1500-2000 m altitudinal zone. Negi (2015) also reported high abundance of the Black Francolin in the 1500-2000 m altitudinal zone of the Garhwal Himalaya. The vegetation characterization and roosting data revealed that this bird gives preference for shrubs, herbs and grasses over tree species. Rubus ellipticus, Rubus niveus and Ficus roxburghii are associated with roosting at a higher altitude and wild berries and fruits of these plants were also found to be a dominant food item in the diet composition of the Black Francolin (Negi 2016).

At a higher elevation, the Black Francolin prefers a higher percentage of cultivated land with abandoned land and cultivated land with forest edges whereas at lower elevation, it prefers cultivated land. The differences in habitat choice can be explained by landscape changes along an altitudinal gradient. At a higher altitude, the majority of agricultural areas were intermixed with adjoining forests of different type. At a higher altitude, the boundaries between agricultural land and forest areas are not clear-cut. Overall, the Black Francolin's preferred habitat is an agro-ecosystem because it provides maximum nutrients and food content (insects, different types of grains, pulses, grass seeds, wild fruits). It was also observed that the Black Francolin prefers a cultivated track with a grass cover because these areas provide higher energy subsidies (Khan 1989). Negi’s (2015) findings also suggest that the Black Francolin prefers lower mixed forest with an agricultural area to dense evergreen and deciduous temperate forest. The Black Francolin was found in habitats with a thicker vegetative cover as well as in scrub habitats rich in shrubs, herbs and tall grasses. However, the bird comes to cultivated croplands and grassland to feed (Roberts 1991; Ali 2002; Mahmood et al. 2010; Khan and Mian 2012).

The analysis of the Black Francolin's nesting sites shows that this bird usually builds nests on the ground and prefers habitats of crop field edges under a permanent grass cover for nesting. Habitats of crop field edges provide nests and chicks with sufficient protection. On the contrary, all the nests built in crop fields were highly exposed to predation and, thus, were found destroyed. During the study, all nests were observed in agricultural land and the areas surrounding it. The survey showed that for nest building, the Black Francolin uses grasses (Imperata species, Saccharum filifolium, Cynodon dactylon) and twigs as well as leaves of wheat and dry leaves of wild peas. All nests were well covered by grass tufts and crops. The same results were reported by Negi and Lakhera (2015) from the Garhwal Himalayan region. These researchers indicated that the Black Francolin's nesting locations were mainly grass clumps near the agro-ecosystem preferred by this bird.

The population abundance and habitat preference of the Black Francolin in Uttarakhand, India have not been studied before. This study provides the baseline data suggesting that habitat choice and vegetation features are very important factors in the Black Francolin's population abundance. The current study also revealed that in the lower altitudinal range the main factors to directly influence the Black Francolin's population are such anthropogenic pressures as unmanaged human settlement, developmental activities, and industrializa- 
tion. The birds mostly preferred an agro-ecosystem because these areas provide higher energy subsidy and suitable shelter cover for their survival. It also prefers mixed- pine, mixed- oak and subtropical mixed deciduous forests near cultivated land and totally neglects pure forest types.

In conclusion, this study shows that the Black Francolin has a wide distribution range in Uttarakhand. The maximum abundance of this bird was observed at higher altitudes while minimum abundance at lower. So, it seems worth emphasizing the combination of factors that explain why the Black Francolin prefers particular types of habitat, whose conservation and management require further studies.

\section{ACKNOWLEDGEMENTS}

The authors gratefully acknowledge the University Grant Commission (UGC), New Delhi for providing UGC BSR Fellowship (No.F.7-77/2007/BSR) and Department of Biotechnology (DBT), New Delhi for Bioinformatics Centre.

\section{REFERENCES}

Ali, S. 2002. The Book of Indian Birds. Third Edition. Oxford: Bombay Natural History Society University Press.

BirdLife International. 2015. Species factsheet: Francolinus francolinus. Accessed December 21, 2015. http://www. birdlife.org/

Bisht, M., P. Lakhera, and A. Chandola-Saklani. 1990. 'The Monal Pheasant: Current Status and Habitat Utilisation in Kedarnath Sanctuary, Garhwal Himalaya.' In Pheasant in Asia, edited by D. Hill, 205-208. UK: World Pheasant Association.

Caughley, G. 1975. Analysis of vertebrate population. New York: John Wiley and Sons.

Chandola-Saklani, A., U. S. Rauthan, P. Lakhera, and K. Pant. 1988. 'Habitat Utilization by Himalayan White Creasted Kaleej pheasant.' In Proceeding of International Rangeland Congress, edited by Punjab Singh, 466-469. New Delhi.

Chandola-Saklani, A., P. Lakhera, and D. K. Sharma. 1994. Management of Himalayan Pheasants: Habitat evaluation and Captive Breeding. Final Technical Report 1999. New Delhi: Department of Environment, MAB, Govt. of India.

Cody, M. L. 1985. Habitat Selection in Birds. New York: Academic Press.

Forcina, G., P. Panayides, M. Guerrini, F. Nardi, B. K. Gupta, F. Mari, and O. F. Al-Sheikhly et al.
2012. 'Molecular evolution of the Asian francolins (Francolinus, Galliformes): A modern reappraisal of a classic study in speciation.' Molecular Phylogenetics and Evolution 65: 523-534.

Johnsgard, P. A. 1988. The Quails, Partridges and Francolins of the World. United Kingdom: Oxford University Press.

Khan, M. S. 1989. Studies on the Biology, Habitat, Distribution Pattern, and Food of the Black Partridge (Francolinus francolinus) in Tehsil Faisalabad. M. Sc. thesis. Faisalabad, Pakistan: University of Agriculture.

Khan, W. A., and A. Mian. 2012. 'Habitat Preference of Black Francolin (Francolinus francolinus) in Lal Suhanra National Park, Pakistan.' Pakistan Journal of Zoology 44: 1593-1601.

Kidwai, Z., K. Sankar, Q. Quershi, and J. A. Khan. 2011. 'Abundance and Habitat Utilisation by Galliformes in the Sariska Tiger Reserve, Rajasthan, India.' International Journal of Galliformes Conservation 2: 54-60.

Kukreti, M., S. Phurailatpam, and M. S. Bisht. 2005. 'Ecology of Chukor Partridge Alectoris chukar in Garhwal Himalaya.' In Proceeding of the Third International Galliformes Symposium, edited by R. A. Fuller, and S. J. Browne, 4-7. Fording bridge U. K.: World Pheasant Association.

Kumar, S., and M. S. Bisht. 2011. 'Population Dynamics of White Crested Kalij Pheasant Lophura leucomelanos hamiltoni (Gray), in Garhwal Himalaya.' Uttar Pradesh Journal of Zoology 31: 65-70.

McGowan, P. J. K., and G. M. Kirwan. 2015. 'Chinese Francolin (Francolinus pintadeanus).' In Handbook of the Birds of the World Alive, edited by del Hoyo, J., A. Elliott, J. Sargatal, D. A. Christie, and E. de Juana. Accessed 21 December 2015. http://www.hbw.com/ node/53388.

Mahmood, S., T. Mahmood, M. Rais, I. Z. Qureshi, and M. S. Nadeem. 2010. 'A Comparative Study on the Population and Habitats of the Gray Francolin, Francolinus pondicerianus and the Black Francolin Francolinus francolinus in Lehri Natur Park, Punjab Pakinstan.' PODOCES 5: 42-53.

Negi, S. 2015. Breeding and Habitat Ecology of Indian Black Francolin (Francolinus francolinus asiae, Bonaparte, 1856) in Garhwal Himalaya. Ph. D. Thesis., Srinagar Garhwal: H. N. B. Garhwal University, Department of Zoology.

Negi, P., and P. C. Lakhera. 2015. 'Breeding habitat preference of Black Francolin Francolinus francolinus asiae in Chamoli district of Uttarakhand, Western Himalaya.' International Journal of Advanced Research 3: 540-544.

Negi, P., and P. C. Lakhera. 2016. 'Food of Black Francolin (Francolinus francolinus asiae) in Garhwal Himalaya in Uttarakhand.' NeBIO 7: 93-95.

Ramesh, K., S. Sathyakumar, and G. S. Rawat. 1999. Ecology 
and Conservation status of Pheasants of the Great Himalayan National Park, Western Himalaya. Final Project Report 1999. Dehradun: Wildlife Institute of India.

Roberts, T. J. 1991. The birds of Pakistan: Regional studies and non-Passeriformes. Pakistan: Oxford University Press. Karachi.

Rodgers, W. A. 1991. A Field Manual of Techniques for Wildlife Census in India. Dehradun: Wildlife Institute of India.

Schemnitz, D. S. 1980. Wildlife Management Technique
Manual. Fourth Edition. Washington: Wildlife Society.

Soldatini, C., Y. V. Albores-Barajas, and B. Pellizzi. 2010.

'Habitat Preferences of High-Altitude Galliformes in Sagarmatha National Park, Nepal.' Italian Journal of Zoology 77: 347-353.

Tucker, G. M., and M. F. Heath. 1994. Birds in Europe: their conservation status. Cambridge: Bird Life International.

Appendix 1. Dominant plant species preferred by the Black

Francolin in Uttarakhand.

\begin{tabular}{|c|c|c|c|c|c|c|c|c|c|c|c|c|c|}
\hline \multirow{3}{*}{ Plant species } & \multicolumn{13}{|c|}{ Sampling sites and altitude (meters above sea level) } \\
\hline & $(1)$ & $(2)$ & (3) & $(4)$ & $(5)$ & (6) & $(7)$ & $(8)$ & (9) & $(10)$ & $(11)$ & $(12)$ & $(13)$ \\
\hline & 288 & 300 & 448 & 700 & 820 & 1095 & 1390 & 1440 & 1500 & 1530 & 1630 & 1730 & 1800 \\
\hline \multicolumn{14}{|l|}{ Trees } \\
\hline Grewia optiva & + & + & + & + & + & + & + & + & + & + & + & + & + \\
\hline Pyrus pashia & + & + & + & + & + & + & + & + & + & + & + & + & + \\
\hline Ficus roxburghii & + & + & + & + & + & + & + & + & + & + & + & + & + \\
\hline Ficus palmata & + & + & + & + & + & + & + & + & + & + & + & + & + \\
\hline Rhus parviflora & + & + & + & + & + & + & + & + & + & - & - & - & - \\
\hline Indigofera sp. & + & + & + & + & + & + & + & + & + & - & - & - & - \\
\hline Acacia catechu & + & + & + & - & - & - & - & - & - & - & - & - & - \\
\hline Delbergia sissoo & + & - & + & - & - & - & - & - & - & - & - & - & - \\
\hline Ficus nemolaris & - & + & - & + & + & + & + & + & + & + & - & - & - \\
\hline Quercus glauca & - & - & - & + & + & + & + & + & - & - & - & - & - \\
\hline Ficus subincisa & - & - & - & - & + & + & + & + & + & + & - & - & - \\
\hline Quercus leucotrichophora & - & - & - & - & - & + & + & + & + & + & - & - & - \\
\hline Pinus roxberghii & - & - & - & - & - & - & + & + & + & + & - & - & - \\
\hline \multicolumn{14}{|l|}{ Shrubs } \\
\hline Arissa opaca & + & + & + & + & + & + & + & + & + & + & + & + & + \\
\hline Ageratina adenophora & + & + & + & + & + & + & + & + & + & + & + & + & + \\
\hline Urtica dioica & + & + & + & + & + & + & + & + & + & + & - & - & - \\
\hline Boehmeria platyphylla & + & + & + & + & + & + & + & + & + & + & + & + & + \\
\hline Ziziphus sp. & + & + & + & + & + & + & + & + & + & - & - & - & - \\
\hline Lantana camara & + & + & + & + & + & + & + & + & - & - & - & - & - \\
\hline Adhatoda sp. & + & + & + & + & + & + & + & - & - & - & - & - & - \\
\hline Mimosa himalayana & + & + & + & + & - & - & - & - & - & - & - & - & - \\
\hline Rubus ellipticus & - & + & - & + & + & + & + & + & + & + & - & - & - \\
\hline Berberis asiata & - & + & - & + & + & + & + & - & - & - & - & - & - \\
\hline Zanthoxylum sp. & - & + & - & + & + & + & + & - & + & - & - & - & - \\
\hline Bryonia laciniosa & - & - & - & + & + & + & + & + & + & - & - & - & - \\
\hline Cotoneaster microphyllus & - & - & - & - & + & + & + & + & + & + & - & - & - \\
\hline Osyris sp. & - & - & - & - & + & + & + & + & + & + & - & - & - \\
\hline Rosa brunonii & - & - & - & - & + & + & + & + & + & + & - & - & - \\
\hline Echinopus echinatus & - & - & - & - & + & - & + & + & + & - & - & - & - \\
\hline Berberis aristata & - & - & - & - & - & + & + & + & + & + & - & - & - \\
\hline Rubus niveus & - & - & - & - & - & - & + & + & + & + & - & - & - \\
\hline Cotoneaster microphyllus & - & - & - & - & - & - & + & + & + & + & - & - & - \\
\hline Pyracantha crenulata & - & - & - & - & - & - & + & + & + & + & - & - & - \\
\hline \multicolumn{14}{|l|}{ Herbs } \\
\hline Artemisia japonica & + & + & + & + & + & + & + & + & + & + & + & + & + \\
\hline Ageratum cynozoides & + & + & + & + & + & + & + & + & + & + & + & + & + \\
\hline Aechmanthera gossypina & + & + & + & + & + & + & + & + & + & + & + & + & + \\
\hline Bidens pilosa & + & + & + & + & + & + & + & + & + & + & + & + & + \\
\hline Eupatorium sp. & + & + & + & + & + & + & + & + & + & + & + & + & + \\
\hline
\end{tabular}




\begin{tabular}{|c|c|c|c|c|c|c|c|c|c|c|c|c|c|}
\hline \multirow[b]{2}{*}{ Plant species } & \multicolumn{13}{|c|}{ Sampling sites and altitude (meters above sea level) } \\
\hline & $\begin{array}{l}(1) \\
288\end{array}$ & $\begin{array}{c}(2) \\
300\end{array}$ & $\begin{array}{l}\text { (3) } \\
448\end{array}$ & $\begin{array}{l}\text { (4) } \\
700\end{array}$ & $\begin{array}{l}(5) \\
820\end{array}$ & $\begin{array}{c}(6) \\
1095\end{array}$ & $\begin{array}{c}(7) \\
1390\end{array}$ & $\begin{array}{c}(8) \\
1440\end{array}$ & $\begin{array}{c}(9) \\
1500\end{array}$ & $\begin{array}{l}(10) \\
1530\end{array}$ & $\begin{array}{l}(11) \\
1630\end{array}$ & $\begin{array}{l}(12) \\
1730\end{array}$ & $\begin{array}{l}(13) \\
1800\end{array}$ \\
\hline Oxalis latifolia & + & + & + & + & + & + & + & + & + & + & + & + & + \\
\hline Reinwardtia indica & + & + & + & + & + & + & + & + & + & + & + & + & + \\
\hline Cynoglossum glochidiatum & + & + & - & - & + & + & + & + & + & - & - & - & - \\
\hline Bidens tripartite & + & + & + & - & - & + & + & - & + & - & - & - & - \\
\hline Desmodium sp. & + & - & + & - & - & + & + & -+ & + & - & - & - & - \\
\hline Crotalaria sp. & + & - & + & - & - & - & + & + & - & - & - & - & - \\
\hline Galium sp. & - & + & + & - & + & + & + & + & + & + & - & - & - \\
\hline Nepeta ciliaris & - & + & - & + & + & - & - & + & - & - & - & - & - \\
\hline Solanum nigrum & - & + & - & + & + & + & + & + & + & + & - & - & - \\
\hline Ajuga parviflora & - & + & - & - & + & + & + & + & + & + & - & - & - \\
\hline Scutellaria sp. & - & + & - & - & + & + & + & + & - & + & - & - & - \\
\hline Gerbera gossypina & - & + & - & - & + & + & - & + & + & + & - & - & - \\
\hline Artemisia nilagirica & - & + & + & - & - & + & + & + & + & - & - & - & - \\
\hline Sida acuta & - & + & + & + & - & + & + & + & - & - & - & - & - \\
\hline Boerhavia diffusa & - & + & + & - & - & + & - & + & + & - & - & - & - \\
\hline Plectranthus sp. & - & + & - & - & + & - & + & - & - & - & - & - & - \\
\hline Euphorbia chamaesyce & - & - & + & - & + & + & - & - & - & - & - & - & - \\
\hline Rumex hastatus & - & - & - & + & + & + & + & + & + & + & - & - & - \\
\hline Fragaria indica & - & - & - & + & + & + & + & + & + & + & - & - & - \\
\hline Ajuga bracteosa & - & - & - & + & + & - & + & + & + & + & - & - & - \\
\hline Fern sp. & - & - & - & + & - & + & + & + & + & + & - & - & - \\
\hline Rumex nepalensis & - & - & - & - & - & + & + & + & + & + & - & - & - \\
\hline Geranium nepalense & - & - & - & - & - & - & + & + & + & + & - & - & - \\
\hline \multicolumn{14}{|l|}{ Grasses } \\
\hline Imperata cylindrical & + & + & + & + & + & + & + & + & + & + & + & + & + \\
\hline Heteropogon contortus & + & + & + & + & + & + & + & + & + & + & + & + & + \\
\hline Poa sp. & + & + & + & + & + & + & + & + & + & + & + & + & + \\
\hline Cynodon dactylon & + & + & + & + & + & + & + & + & + & - & - & - & - \\
\hline Brachiaria distachya & + & + & + & + & + & + & + & - & - & - & - & - & - \\
\hline Eleusine indica & + & + & + & - & - & + & + & + & - & - & - & - & - \\
\hline Arundinaria sp. & + & + & + & + & + & + & - & - & - & + & - & - & - \\
\hline Apluda mutica & + & - & + & + & + & + & - & + & - & - & - & - & - \\
\hline Saccharum filifolium & - & + & + & - & - & + & + & - & - & + & - & - & - \\
\hline Andropogon munroi & - & + & - & + & + & + & + & + & + & + & - & - & - \\
\hline Calamagrostis sp. & - & + & - & - & + & + & + & + & + & + & - & - & - \\
\hline Apluda aristata & - & + & - & + & + & + & + & - & - & + & - & - & - \\
\hline Chrysopogon gryllus & - & + & - & - & + & + & + & + & - & - & - & - & - \\
\hline Hemarthria compressa & - & + & - & - & + & + & + & + & - & - & - & - & - \\
\hline Brachiaria villosa & - & - & - & - & + & + & + & + & + & + & - & - & - \\
\hline Themeda arundinacea & - & - & - & - & + & + & + & + & + & - & - & - & - \\
\hline Echinochloa crusgalli & - & - & - & - & + & + & + & + & - & - & - & - & - \\
\hline Cyperus niveus & - & - & - & - & + & + & + & + & + & - & - & - & - \\
\hline Anthraxon prionodes & - & - & - & - & + & + & + & + & + & - & - & - & - \\
\hline Chrysopogon sp. & - & - & - & - & - & + & + & + & + & + & - & - & - \\
\hline Oplismenus sp. & - & - & - & - & - & + & + & + & + & + & - & - & - \\
\hline Capillipedium assimile & - & - & - & - & - & + & + & + & + & - & - & - & - \\
\hline
\end{tabular}

Note: $+=$ Presence of species, $-=$ Absence of species. 